\title{
Effectiveness of expanded clay as a bacteria carrier for self-healing concrete
}

\author{
Sanghyun Han ${ }^{1}$, Eun Kyung Choi ${ }^{2}$, Woojun Park ${ }^{3}$, Chongku Yi ${ }^{4}$ and Namhyun Chung ${ }^{1 *}$ (]
}

\begin{abstract}
Cracking of concrete over time, is a natural phenomenon. Longer service life of concrete structures is desirable. Self-healing concrete using bacteria, which could form $\mathrm{CaCO}_{3}$ crystals for crack sealing, has promised benefits to reduce cost for concrete maintenance, because cracks could be autonomously repaired without human intervention. However, because of harsh concrete internal environment render the effectiveness depending on the bacteria viability within concrete. In this study, expanded clay (EC) was used as a carrier, to protect bacteria (Lysinibacillus boronitolerans YS11) from the harsh environment during the process. Existence of bacteria inside EC was observed using electron microscopy. When exposed to bacterial solution of $1.0 \times 10^{9} \mathrm{cell} / \mathrm{s} / \mathrm{mL}$, bacterial density within $\mathrm{EC}$ reached approximately $0.82 \times 10^{7}$ cells/g of dry EC. Extent of bacterial viability within EC, submerged to solution containing $1.0 \times 10^{8}$ cells $/ \mathrm{mL}$, was $53.6 \%$ of free bacteria solution containing $1.0 \times 10^{7}$ cells $/ \mathrm{mL}$, as measured with fluorescein diacetate assay. When rate of calcium carbonate formation was measured with $\mathrm{Ca}^{2+}$ disappearance, rates were comparable between bacteria within EC (submerged to bacterial solution containing $1.0 \times 10^{8} \mathrm{cell} / \mathrm{s} / \mathrm{mL}$ ) and free bacteria $\left(1.0 \times 10^{7}\right.$ cells $\left./ \mathrm{mL}\right)$. This finding indicates that bacteria with $\mathrm{EC}$ is very active for generation of $\mathrm{CaCO}_{3}$ within $\mathrm{EC}$. All experimental results suggest that EC may be an adequate bacteria carrier for self-healing concrete.
\end{abstract}

Keywords: Bacterial biomineralization, Expanded clay, Self-healing concrete, Viability

\section{Introduction}

Concrete is a construction material that cannot be replaced, with other modern technologies yet. Thus, concrete is irreplaceable construction material in terms of availability, versatility, and economy. However, concrete is not permanent material. Cracks in concrete shorten the life of concrete [1,2]. Accordingly, the importance and necessity of self-healing concrete has been emphasized [3, 4]. In bacterial-based self-healing concrete, calcium carbonate $\left(\mathrm{CaCO}_{3}\right)$ produced by bacteria heals the crack [5-7]. Because of high $\mathrm{pH}$ inside concrete, shear forces by mixing, and shrinkage during concrete drying, bacterial viability is very limited for appropriate healing ability of self-healing concrete. To solve such problems, various carriers have been studied to protect bacteria [8-10].

\footnotetext{
*Correspondence: nchung@korea.ac.kr

${ }^{1}$ Department of Biosystems Engineering, College of Life Sciences

and Biotechnology, Korea University, Seoul 02841, Korea

Full list of author information is available at the end of the article
}

Different types of carriers, such as melamine-based microcapsules, diatomaceous earth, polyurethane foam, silica gel, and polyurethane (PU), hydrogel have been proposed to protect bacterial cells. However, the majority of these carriers had negative impact on concrete mechanical properties [11]. Thus, it is needed to search for other kinds of carriers. In this study, expanded clay was tested as a carrier of bacteria Lysinibacillus boronitolerans YS11, which has carbonatogenesis activity of microbially induced calcium carbonate precipitation (MICP) [12]. The purpose of this study was to observe potential usability of expanded clay as a bacterial carrier for self-healing concrete.

\section{Materials and methods Bacteria Lysinibacillus boronitolerans YS11 was isolated from rhizosphere soil of Miscanthus sacchariflorus using biomineralization-inducing B4 medium, which is often used for screening of possible calcium carbonate precipi- tating bacteria [8].}


Immobilization of bacteria in expanded clay

Lysinibacillus boronitolerans YS11 was cultivated in Lunia-Bertani (LB) broth at $37^{\circ} \mathrm{C}$ for $20 \mathrm{~h}$. Growth media was replaced with phosphate buffered saline (PBS, $\mathrm{pH}$ 7.5) [8]. Expanded clays (diameter 2-5 mm; Liapor, Germany) were autoclaved at $121{ }^{\circ} \mathrm{C}$ for $20 \mathrm{~min}$. Then, the expanded clay (EC) was immersed in PBS containing bacteria under a vacuum chamber (Cast N' Vac 1000, Buehler, Germany), until bubble generation stops. As necessary, the surface of EC was gently sprayed with $80 \%$ ethanol, and exposed to ultraviolet light for $10 \mathrm{~min}$ with mixing to remove bacteria on the surface. Then, the EC was collected to be dried in an oven at $70{ }^{\circ} \mathrm{C}$ for 2 days.

\section{Observation of bacteria within carrier}

Bacteria-immobilized EC was gently hammered to obtain pieces of EC. Then, broken pieces were fixed first with Karnovsky's solution (2\% paraformaldehyde, $0.1 \mathrm{M}$ phosphate buffer, and 2.5\% glutaraldehyde, $\mathrm{pH}$ of 7.2) for $2 \mathrm{~h}$ and then, with $2 \%$ osmium tetroxide solution for $2 \mathrm{~h}$. Fixed samples were gradually dehydrated with ethanol $(30,50,70,100 \%)$ for $10 \mathrm{~min}$ at each gradient, and placed onto an aluminum stub for 4 days to be dried in clean bench [8]. Prepared samples were observed with scanning electron microscope (JSM-7401F, FE-SEM, JEOL, USA) to find bacteria within EC.

\section{Performance tests of bacteria-immobilized expanded clay as carrier}

For a performance test, EC was immersed in PBS solution containing bacteria $\left(1.0 \times 10^{6}, 1.0 \times 10^{7}, 1.0 \times 10^{8}\right.$ cells/ $\mathrm{mL}$ ) after surface-sterilization, and dried as described above. The 3 bacteria-immobilized carrier was shattered, using a hammer mill. Each $1 \mathrm{~g}$ of the broken pieces received $9 \mathrm{~mL}$ of $\mathrm{PBS}$ solution to be shaken gently a few times. Then, each of the PBS solution was serially diluted, to be spread onto LB agar to count the colony forming unit (CFU) [13, 14], by which immobilizing capacity (CFU/g of dry EC) of expanded clay was calculated.

Fluorescein diacetate assay (FDA) was also performed to measure viability of immobilized bacteria [15]. One gram of shattered EC above received $15 \mathrm{~mL}$ of potassium phosphate buffer (60 mM, pH 7.6) and $0.2 \mathrm{~mL}$ FDA stock solution $(1 \mathrm{mg} / \mathrm{mL})$ to be shaken gently by hand, and placed on an orbital incubator at $30{ }^{\circ} \mathrm{C}$ for $20 \mathrm{~min}$. Then, $15 \mathrm{~mL}$ of chloroform/methanol (2:1 v/v) was added, to the solution of $\mathrm{EC}$ for reaction termination. The solution of EC was centrifuged at $900 \times g$ for $3 \mathrm{~min}$. The supernatant was filtered using Whatman No. 2 into conical flasks, and absorbance of filtrates was measured at $490 \mathrm{~nm}$ with spectrophotometer (EL-800, DI Biotech, Korea). It is known that colorless fluorescein diacetate is hydrolyzed by free and membrane bound enzymes, to release a colored end product of fluorescein, which can be measured by spectrophotometry $[15,16]$.

\section{Measurement of carbonatogensis ability of bacteria-immobilized expanded clay}

To confirm bacteria ability of microbially induced calcium carbonate precipitation (MICP), the level of calcium ion consumption was measured, using calcium-ion selective electrode (ISE) (Thermo Fisher Scientific, USA). Control medium (30 mL) contained calcium ion source $(0.25 \%$ calcium lactate) and nutrient for bacteria ( $0.4 \%$ yeast extract). Extent of calcium ion consumption was measured for control medium, EC only, bacteria $\left(1.0 \times 10^{6}\right.$ cells $\left./ \mathrm{mL}\right)$ only, and EC-immobilized bacteria $\left(1.0 \times 10^{6}\right.$ cells/g of dry EC). Extents of calcium consumption were measured for $24 \mathrm{~h}$.

\section{Results and discussion}

In this study, expanded clay (EC) was proposed as a carrier of bacteria for cabonatogenesis in concrete. That is, $\mathrm{EC}$ as a carrier could protect bacteria from harsh concrete environment, so that more calcium carbonate precipitation is induced within concrete crack than without a carrier. For EC to be a carrier, it must show that bacteria YS11 strain can enter or be immobilized into channels within EC, at which bacteria can be protected from a harsh environment of mechanical stress, high $\mathrm{pH}$, and temperature. Figure 1A shows an SEM image of the inner part of porous EC, at which copious empty channels and space were observed. That is, space or channels ranging from approximately $10-100 \mu \mathrm{m}$ micrometers were observed inside EC. As bacteria YS11 entered into EC inner part, a number of bacteria was observed to be attached on the inner surface of EC (Fig. 1B).

To know how many bacteria could enter into EC, bacteria-immobilizing or holding capacity (CFU/g of dry EC) of EC needed to be measured. About 10 pieces of EC were submerged into PBS solution containing $1.0 \times 10^{6}$, $1.0 \times 10^{7}$, and $1.0 \times 10^{8}$ bacteria cells $/ \mathrm{mL}$. Then, the bacteria-immobilized EC was surface-sterilized, and dried as described in "Materials and methods" section. The three different kinds of immobilized ECs were shattered into small pieces. Each $1.0 \mathrm{~g}$ of the broken pieces was used to measure colony forming unit (CFU). Immobilizing capacity (CFU/g of dry EC) of expanded clay was approximately $0.80 \times 10^{5}, 1.08 \times 10^{6}$ and $0.82 \times 10^{7} \mathrm{CFU} / \mathrm{g}$ of dry EC with $1.0 \times 10^{7}, 1.0 \times 10^{8}$, and $1.0 \times 10^{9}$ bacteria cells/ $\mathrm{mL}$, respectively (Fig. 2). This means that approximately $1 \%$ bacteria cells in each $\mathrm{mL}$ of bacterial solution were immobilized into $1 \mathrm{~g}$ of dry EC.

Expanded clay has a disadvantage as a bacteria carrier, since it has physically very limited space for bacteria 

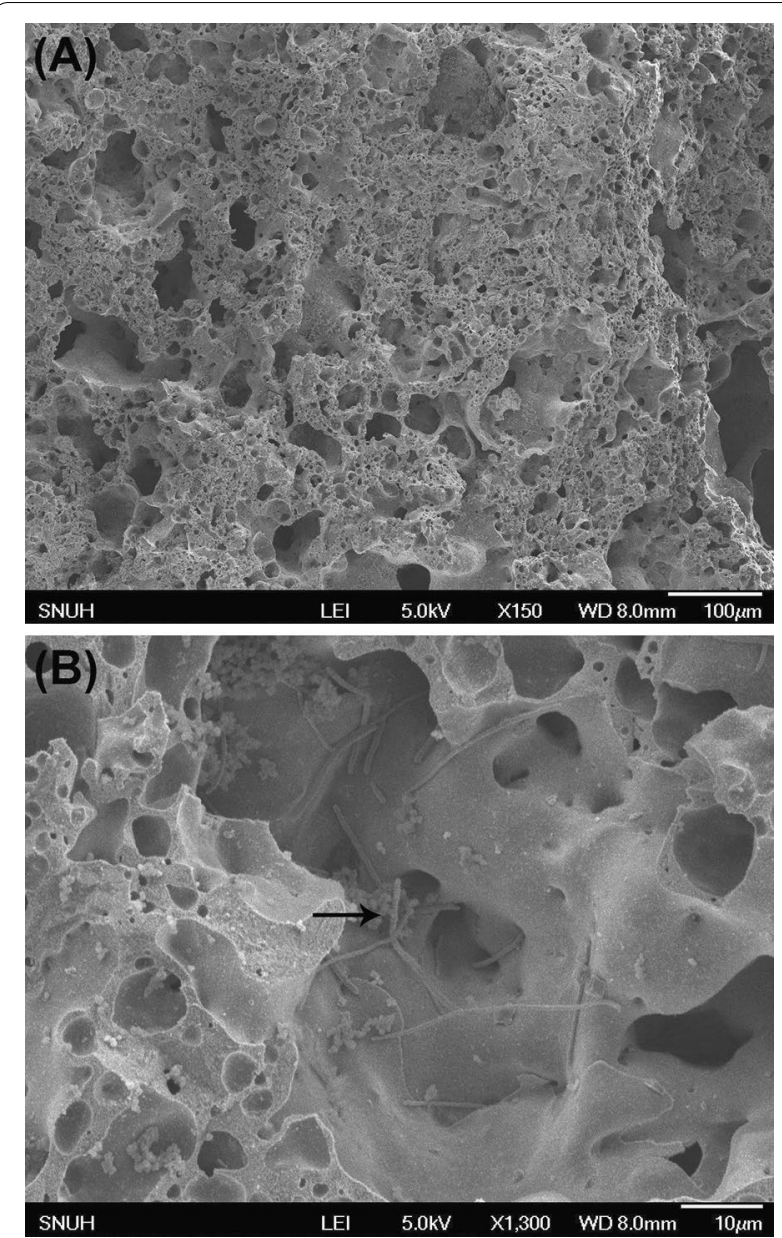

Fig. 1 Scanning electron microscope (SEM) images of expanded clay without bacteria YS11 (A) and with bacteria YS11 (B). Arrow in B indicates bacteria YS11 of bar shape

immobilization. However, unlike other carriers, strength to withstand the internal environment (i.e., heat and pressure) of concrete is one of the most important advantages as a bacteria carrier of self-healing concrete [17]. To examine viability extent of immobilized bacteria, FDA assay was performed (Fig. 3). Immobilized bacteria, made by submerging EC into free bacteria solution containing $1.0 \times 10^{8}$ cells $/ \mathrm{mL}$, had approximately $53.6 \%$ activity of control solution, containing free bacteria of $1.0 \times 10^{7}$ cells $/ \mathrm{mL}$. Viability extent of immobilized bacteria, was slightly higher (11.6\%) than that of free bacteria containing $1.0 \times 10^{6}$ cells $/ \mathrm{mL}$. Results showed that immobilized bacteria are alive, and also have enzymatic activity so that it may have cabonatogenesis ability; that is, selfhealing ability for concrete crack [11]. Because EC was submerged into $1.0 \times 10^{8}$ cells $/ \mathrm{mL}$, bacteria-immobilized EC was expected to have approximately $1.0 \times 10^{6} \mathrm{CFU} / \mathrm{g}$ of dry EC and its corresponding viability. As expected, EC-immobilized bacteria, had almost the same degree of

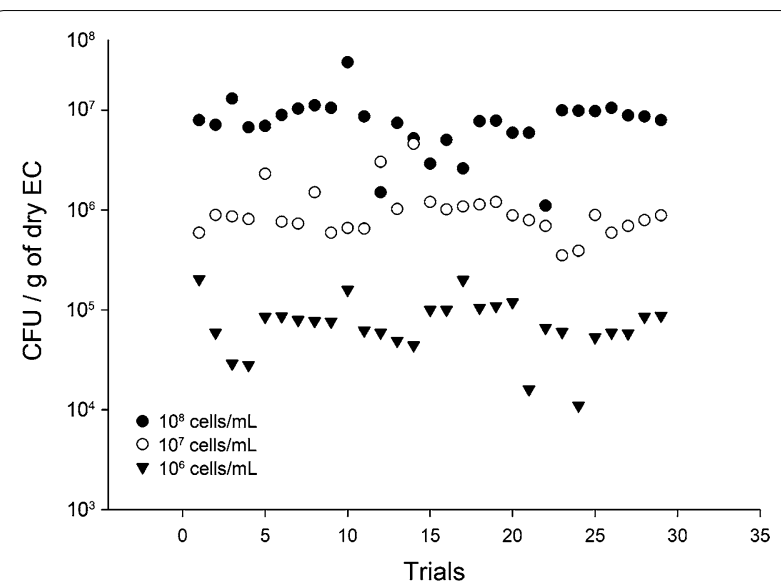

Fig. 2 Colony forming unit (CFU) assay of bacteria YS11 that was immobilized into expanded clay using different bacterial concentrations. Expanded clay was submerged into PBS containing various bacterial concentrations $\left(1.0 \times 10^{6}, 1.0 \times 10^{7}, 1.0 \times 10^{8}\right.$ cell/ $\mathrm{mL})$ and extent of immobilization were measured with CFU assay $(n=30)$

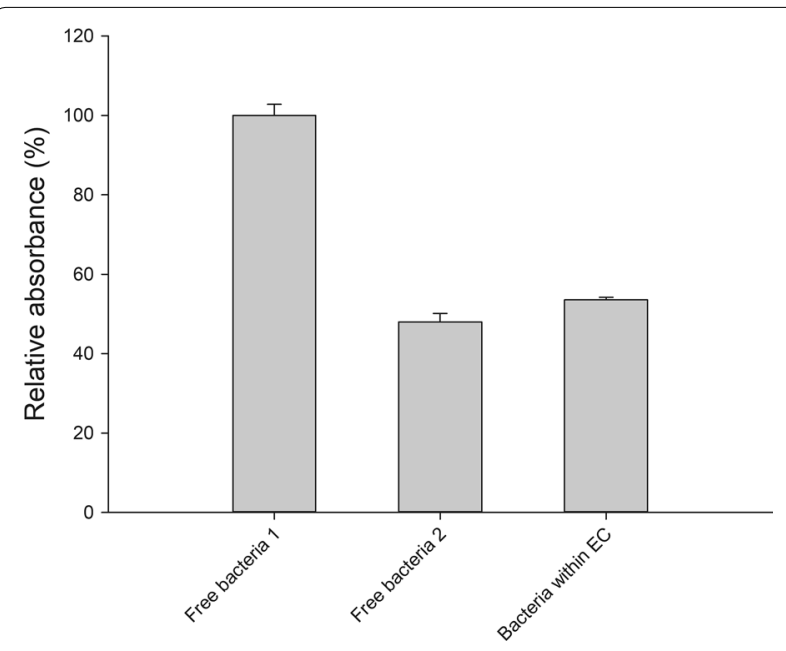

Fig. 3 Fluorescein diacetate assay (FDA) of expanded clay-immobilized bacteria. Extent of microbial enzyme activity were measured with free bacteria $1\left(1.0 \times 10^{7}\right.$ cell/mL), free bacteria 2 $\left(1.0 \times 10^{6} \mathrm{cell} / \mathrm{mL}\right)$, and EC-immobilized bacteria submerged into bacteria solution of $1.0 \times 10^{8} \mathrm{cell} / \mathrm{mL}$. Relative absorbance (\%) were calculated by comparison to absorbance of free bacteria 1 $\left(1.0 \times 10^{7} \mathrm{cell} / \mathrm{mL}\right)$

viability with free bacteria containing $1.0 \times 10^{6}$ cells $/ \mathrm{mL}$. This may be due to the fact that bacteria-immobilized $\mathrm{EC}$, were broken into small pieces for the experiment. Thus, it may be exposed outside EC, more directly than EC without breaking.

To confirm biomineralization or carbonatogenesis activity by the EC-immobilized bacteria, extent of calcium ion consumption was measured for $24 \mathrm{~h}$ using 


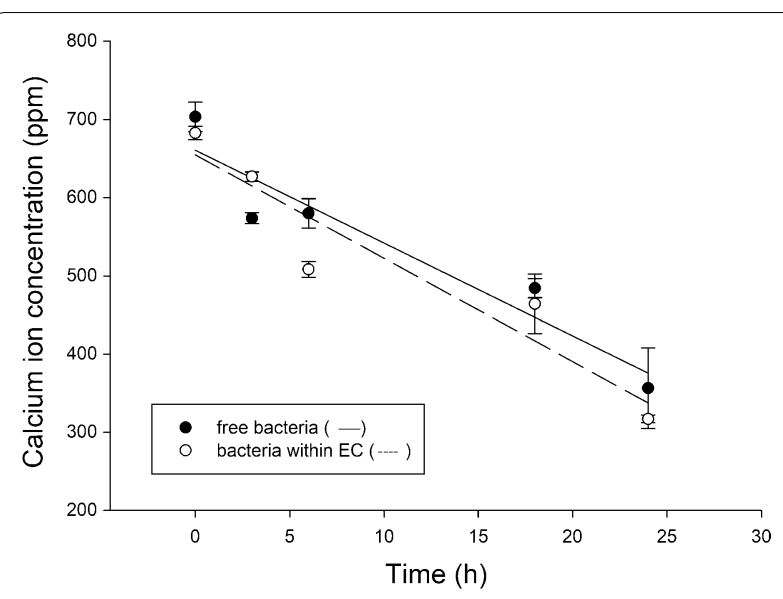

Fig. 4 Change in calcium ion concentration with time. Free bacteria $\left(1.0 \times 10^{6} \mathrm{cell} / \mathrm{s} / \mathrm{mL}\right)$ and EC-immobilized bacteria $\left(1.0 \times 10^{6} \mathrm{cell} / \mathrm{s} \mathrm{g}\right.$ of dry EC) were used. Expanded clay was submerged into bacterial solution of $1.0 \times 10^{8} \mathrm{cell} / \mathrm{mL}$ and processed as described in "Materials and methods" section. No carbonatogenesis activity was observed for control medium and EC only

calcium-ion selective electrode (ISE), since there is no direct method to measure extent of calcium carbonate formation within EC $[18,19]$ As shown in Fig. 4, decreases in calcium ion concentration were observed, with free bacteria $\left(1.0 \times 10^{6}\right.$ cells $\left./ \mathrm{mL}\right)$ and EC-immobilized bacteria $\left(1.0 \times 10^{6}\right.$ cells/g of dry EC). Decreasing extent of calcium ion with time were very similar at approximately $14.8 \mathrm{ppm} / \mathrm{h}$, for free and immobilized bacteria without statistical difference. This result suggests that while control medium and EC only had no carbonatogenesis activity, EC-immobilized bacteria was active for calcium carbonate formation as much as free bacteria.

In this study, expended clay (EC) was tested as a carrier of bacteria, which have self-healing ability for concrete crack. Prevention or crack-healing is necessary, for cost reduction during building construction. Cracks in concrete materials form gradually with time so that inclusion of bacteria for crack self-healing capability, may be needed at the time of building construction [20]. However, direction inclusion of bacteria in concrete is problematic, due to heat during curing and pressure by concrete. In addition, there is no food for bacterial in concrete. Thus, use of the bacterial carrier is necessary, for proper crack curing of concrete. There could be many carriers for this purpose [21, 22] as well as for agricultural purpose [23]. Here, we confirmed that expended clay may be an adequate bacterial carrier, for crack selfhealing of concrete. First, a part of bacteria easily entered into EC, by submerging as confirmed by SEM observation and CFU test (Figs. 1, 2). Second, bacteria L. boronitolerans YS11 was viable after immobilization within EC, as tested with FDA (Fig. 3). Third, bacteria YS11 formed calcium carbonate as suggested, by consumption of calcium ion. All results suggest that EC could be used as a carrier of bacteria, for self-healing of concrete. However, it is necessary to perform more tests for other kinds of $\mathrm{EC}$ in the future, since there are many other ECs in the market made by various companies [24].

\section{Authors' contributions}

$\mathrm{SH}$ analyzed the data and wrote the paper. EC provided microscope technical assistance to $\mathrm{SH}$ and helped with the data collection. WP provided advice of experimental design. CY helped the preparation of experiments. NC revised and edited the manuscript and supervised the work. All authors read and approved the final manuscript.

\section{Author details}

${ }^{1}$ Department of Biosystems Engineering, College of Life Sciences and Biotechnology, Korea University, Seoul 02841, Korea. ${ }^{2}$ Department of Pathology, Seoul National University Hospital, Seoul 03080, Korea. ${ }^{3}$ Laboratory of Molecular Environmental Microbiology, Department of Environmental Science and Ecological Engineering, Korea University, Seoul 02841, Korea. ${ }^{4}$ School of Civil, Environmental and Architectural Engineering, Korea University, Seoul 02841, Korea

\section{Acknowledgements}

This study was supported by a Grant (17SCIP-B103706-03) from the Construction Technology Research Program funded by the Ministry of Land, Infrastructure and Transport of the Korean government.

\section{Competing interests}

The authors declare that they have no competing interests.

\section{Publisher's Note}

Springer Nature remains neutral with regard to jurisdictional claims in published maps and institutional affiliations.

Received: 8 November 2018 Accepted: 20 November 2018

Published online: 30 March 2019

\section{References}

1. Vijay K, Murmu M, Deo SV (2017) Bacteria based self-healing concrete - a review. Constr Build Mater 152:1008-1014

2. Wang JY, Mignon A, Snoeck D, Wiktor V, Van Vlierberghe S, Boon N, De Belie N (2015) Application of modified-alginate encapsulated carbonate producing bacteria in concrete: a promising strategy for crack self-healing. Front Microbiol 6:1088

3. Chen HC, Qian CX, Huang HL (2016) Self-healing cementitious materials based on bacteria and nutrients immobilized respectively. Constr Build Mater 126:297-303

4. Alghamri R, Kanellopoulos A, Al-Tabbaa A (2016) Impregnation and encapsulation of lightweight aggregates for self-healing concrete. Constr Build Mater 124:910-921

5. de Koster SAL, Mors RM, Nugteren HW, Jonkers HM, Meesters GMH, van Ommen JR (2015) Geopolymer coating of bacteria-containing granules for use in self-healing concrete. Procedia Eng 102:475-484

6. Van Tittelboom K, De Belie N, De Muynck W, Verstraete W (2010) Use of bacteria to repair cracks in concrete. Cem Concr Res 40:157-166

7. De Muynck W, De Belie N, Verstraete W (2010) Microbial carbonate precipitation in construction materials: a review. Ecol Eng 36:118-136

8. Lee YS, ParkW (2018) Current challenges and future directions for bacterial self-healing concrete. Appl Microbiol Biotechnol 102:3059-3070

9. Wang JY, Van Tittelboom K, De Belie N, Verstraete W (2012) Use of silica gel or polyurethane immobilized bacteria for self-healing concrete. Constr Build Mater 26:532-540

10. Seifan M, Samani AK, Berenjian A (2016) Bioconcrete: next generation of self-healing concrete. Appl Microbiol Biotechnol 100:2591-2602 
11. Seifan M, Ebrahiminezhad A, Ghasemi Y, Samani AK, Berenjian A (2018) Amine-modified magnetic iron oxide nanoparticle as a promising carrier for application in bio self-healing concrete. Appl Microbiol Biotechnol 102:175-184

12. Lee YS, Kim HJ, Park W (2017) Non-ureolytic calcium carbonate precipitation by Lysinibacillus sp. YS11 isolated from the rhizosphere of Miscanthus sacchariflorus. J Microbiol 55:440-447

13. Lim E-S (2018) Preparation and functional properties of probiotic and oat-based synbiotic yogurts fermented with lactic acid bacteria. Appl Biol Chem 61:25-37

14. Lee E-J, Kim G-R, Ameer K, Kyung H-K, Kwon J-H (2018) Application of electron beam irradiation for improving the microbial quality of processed laver products and luminescence detection of irradiated lavers. Appl Biol Chem 61:79-89

15. Adam G, Duncan H (2001) Development of a sensitive and rapid method for the measurement of total microbial activity using fluorescein diacetate (FDA) in a range of soils. Soil Biol Biochem 33:943-951

16. Green VS, Stott DE, Diack M (2006) Assay for fluorescein diacetate hydrolytic activity: optimization for soil samples. Soil Biol Biochem 38:693-701

17. Stuckrath C, Serpell R, Valenzuela LM, Lopez M (2014) Quantification of chemical and biological calcium carbonate precipitation: performance of self-healing in reinforced mortar containing chemical admixtures. Cem Concr Compos 50:10-15

18. Luo M, Qian CX, Li RY (2015) Factors affecting crack repairing capacity of bacteria-based self-healing concrete. Constr Build Mater 87:1-7

19. Wiktor V, Jonkers HM (2011) Quantification of crack-healing in novel bacteria-based self-healing concrete. Cem Concr Compos 33:763-770

20. Jonkers HM, Thijssen A, Muyzer G, Copuroglu O, Schlangen E (2010) Application of bacteria as self-healing agent for the development of sustainable concrete. Ecol Eng 36:230-235

21. Khaliq W, Ehsan MB (2016) Crack healing in concrete using various bioinfluenced self-healing techniques. Constr Build Mater 102:349-357

22. Seifan M, Sarmah AK, Ebrahiminezhad A, Ghasemi Y, Samani AK, Berenjian A (2018) Bio-reinforced self-healing concrete using magnetic iron oxide nanoparticles. Appl Microbiol Biotechnol 102:2167-2178

23. Lee K-C, Yoon YS, Li F-Z, Eun J-B (2017) Effects of inlet air temperature and concentration of carrier agents on physicochemical properties, sensory evaluation of spray-dried mandarin (Citrus unshiu) beverage powder. Appl Biol Chem 60:33-40

24. Elrahman MA, Chung S-Y, Stephan D (2018) Effect of different expanded aggregates on the properties of lightweight concrete. Mag Concr Res 71:95-107. https://doi.org/10.1680/jmacr.17.00465

\section{Submit your manuscript to a SpringerOpen ${ }^{\circ}$ journal and benefit from:}

- Convenient online submission

- Rigorous peer review

- Open access: articles freely available online

- High visibility within the field

- Retaining the copyright to your article

Submit your next manuscript at $\boldsymbol{\nabla}$ springeropen.com 